\title{
Recombination as a motor of host switches and virus emergence: geminiviruses as case studies Pierre Lefeuvre $^{1}$ and Enrique Moriones ${ }^{2}$
}

Genetic recombination facilitates the transfer of genetic information in a parasexual reproduction manner even between distantly related species. Within the Geminiviridae family, a group of plant-infecting viruses that severely constrain cropping systems worldwide, it is highly suspected that recombination was pivotal in the emergence as a devastating phytopathological problem. Whereas extensive evidence of recombination suggests that this mechanism might be adaptive in this family, direct demonstration remains scarce. Here we assemble lines of evidences indicating that recombination was crucial in driving host switches and further emergence of geminiviruses, making these viruses such successful plant pathogens.

\begin{abstract}
Addresses
${ }^{1}$ CIRAD, UMR PVBMT, Pôle de Protection des Plantes, 7 chemin de I'IRAT, Saint-Pierre, lle de la Réunion 97410, France

${ }^{2}$ Instituto de Hortofruticultura Subtropical y Mediterránea "La Mayora" (IHSM-UMA-CSIC), Consejo Superior de Investigaciones Científicas, Estación Experimental "La Mayora", 29750 Algarrobo-Costa, Málaga, Spain
\end{abstract}

Corresponding author: Moriones, Enrique (moriones@eelm.csic.es)

Current Opinion in Virology 2015, 10:14-19

This review comes from a themed issue on Emerging viruses: interspecies transmission

Edited by Antoine Gessain and Fernando Garcia-Arenal

For a complete overview see the Issue and the Editorial

Available online 2nd Janurary 2015

http://dx.doi.org/10.1016/j.coviro.2014.12.005

1879-6257/C 2014 Elsevier B.V. All rights reserved.

\section{Introduction}

Genetic recombination allows parental viruses to derive genetic information to their progeny in a parasexual reproduction manner. This mechanism is a key process in the evolution of many virus families and has been extensively recorded for members of the family Geminiviridae [1-4]. Geminiviruses are plant-infecting circular single stranded (ss) DNA viruses that severely constrain production in a variety of cropping systems throughout the world [5-7]. They comprise seven genera that differ in terms of phylogenetic relationships, genome structure, host range and insect vector [8]. Besides evolving at substitutions rates equivalent to those found for RNA viruses [9], in this virus family, extensive evidence of recombination is available at every level of the diversity spectrum [10]. As recorded also for other virus groups [11], this mechanism was most probably essential in the macroevolution and the emergence process (see $\left[1,12^{\circ}, 13\right]$ for a review of recombination for the ssDNA viruses in general).

Recombination in geminiviruses facilitates the transfer of genetic information even between distantly related species in such extent that their genomic organization is thought to have evolved to maximize its adaptive value and minimize potentially deleterious effects [1]. In fact, the risk to produce defective progeny is high for geminiviruses because of their highly compacted genome $(\sim 2.7 \mathrm{~kb})$ with overlapping genes, multifunctional proteins and optimized interactions between different parts and proteins it encodes. While the preservation of coevolved interactions is supported by wide experimental and analytical information, in some cases recombinants with novel abilities to interact with hosts or vector might arise. Thus, for example, the ability to infect a particular host depends in part on the balance between host defenses and virus counterdefense. Among host defenses, it is now apparent that gene silencing is an essential plant antiviral mechanism [14]. However, as for other plant viruses, geminiviruses encode proteins that can suppress gene silencing [15] in a host dependent manner [16 ${ }^{\circ}$ ]. Genetic exchanges involving these proteins might drive host shift and emergence $\left[16^{\bullet}, 17\right]$.

The abilities of geminiviruses to rapidly generate polymorphisms through mutations [9] and combine new genetic forms through recombination were probably essential in responding to the numerous niche extensions events offered within the context of modern agriculture [1,5-7,18-21]. However, despite a large amount of indirect evidence and some degree of speculation, there are few well supported examples of this having occurred in nature (see $\left[4,22,23,24^{\circ}\right]$ for good examples).

\section{Recombination patterns in geminiviruses}

Whereas non-homologous recombination (during which genome regions get rearranged, duplicated, deleted) is mostly apparent above the genus level in the Geminiviridae family, homologous recombination is a widespread phenomenon as almost every geminivirus is the descendent of some inter-species or inter-strain recombinant [10]. Importantly, analyses of viral sequences obtained from both the environment and experimental studies revealed that recombination breakpoints are generally 
not randomly distributed with conserved recombination hot spots and cold spots [10]. Studies demonstrated that these distribution patterns are strongly influenced by mechanistical factors preserving interaction networks $\left[1,25,26,27^{\bullet \bullet}\right]$. Remarkably, recombination is intimately associated with the replication process of geminiviruses. It notably involves the so-called 'recombination dependent replication' mechanism that is able to recover fragments of geminiviral DNA that may result from incomplete synthesis or from nucleolytic attack to create recombinant viruses $[28,29]$. Doing so, it has the potential to create large number of recombinant viruses displaying specific recombination patterns (e.g. the notorious recombination hot-spot around the origin of replication [10]) when multiple viruses co-infect the same cell [1].

While mechanistic predisposition profoundly affects the recombination patterns, these also bear severe imprints of selection. Recombination breakpoint distribution patterns are partially attributable to natural selection disfavouring survival of recombinants in which co-evolved intra-genome interaction networks are disrupted [25,30]. Whereas the vast majority of recombinant forms, as most mutants, are likely of poorer fitness than the parents [26,31], recombinants bearing favourable combinations [27] might outcompete the parental viruses and become prevalent in the population.

It is clearly apparent from the literature that genetic material is exchanged between viruses participating into epidemics on distinct hosts. Although it does not prove that recombination allowed host shift or range extension, it clearly demonstrated exchanges of genetic material between distinct viral diversity pools.

Additionally in the Begomovirus genus of the Geminiviridae family, where bipartite genomes occur, mixed infections provide opportunities for heterologous genome component reassortment, also-called pseudo-recombination. Evidences of exchange, loose or gain of components during the evolution of begomoviruses is shown in natural infections [32-34]. Importantly, pseudorecombination involving non-essential components such as betasatellites, can modulate the expression of the disease in a host-dependent manner, and drive host shift [35-37] providing another determinant for host adaptation.

\section{Recombination as a driving force of emergence}

Besides experimental studies demonstrating alteration of ecology and fitness following recombination between geminiviruses [22,38-45], evidences accumulate for recombination as in natura mechanism of modification of host ranges $\left[4,22,32,40,46-48,49^{\bullet \bullet}\right]$. These notably include the invasive spread of tomato yellow leaf curl disease (TYLCD)-associated begomoviruses across the
Western Mediterranean during the past three decades $[22,50]$ or the emergence of maize streak disease as a major agricultural threat throughout the African continent $[4,51]$. It should be highlighted that these diseases were absent in the centre of origin of the host plants (both from the Americas) and have emerged in the areas where these plants where later introduced. Recombination might have contributed to the likely host switches events and adaptation of locally circulating geminiviruses.

\section{Recombination as a driving force in dicot geminiviruses: begomoviruses}

Begomovirus is one of the largest plant virus genus comprising almost 300 viral species [52]. Several lines of evidence indicate that the emergence of a highly polyphagous and invasive type of the vector of begomoviruses, the whitefly (Hemiptera: Aleyrodidae) Bemisia tabaci, is contributing to transferring begomoviruses among a large set of distinct hosts [7,53], increasing the opportunities of mixed infection and further diversification through recombination [21]. Some instances of such events have been recorded with, for example, the recent pandemic on cassava in Africa caused by a recombinant virus with an extremely increased severity [54,45], or the emergence of the resistance-breaking recombinant virus named cotton leaf curl Burewala virus (CLCuBuV) that causes devastating damage to cotton production in India and Pakistan [24]. One of the best studied examples is the one that refers to TYLCD-associated begomoviruses. The TYLCD has emerged during the last decades in almost every region of the world where tomato is commercially grown [50] and is caused by a complex of begomovirus species related to the highly invasive tomato yellow leaf curl virus (TYLCV) [55]. Complex recombinationderived progenies were shown to arise at high frequencies and in relatively short periods during mixed infections of TYLCD-related species $[3,56]$ or with other distantly related begomoviruses [30,57]. Interestingly, although natural selection preserves co-evolved intra-genome interaction networks [30], numerous and diverse viable recombinants can be produced during mixed infections $\left[30,57^{\circ}\right]$ or artificially [58], highlighting the tolerance to disruption of begomoviruses genomes. Scarce information, however, is available on the fitness of recombinants arising in natura. Again, studies conducted on natural populations of TYLCD-associated viruses inform about this aspect. In Spain and Italy, a diversity of recombinant viruses between TYLCD-associated begomoviruses was described [22,23,59]. Importantly, both field and experimental studies demonstrated that successful recombinant viruses exhibited host shift in respect to parental viruses, being able to infect a larger set of hosts [22,23]. This was the case, for example, of the recombinant virus named tomato yellow leaf curl Málaga virus (TYLCMalV) that has an enlarged host range and outcompeted the parental viruses in Phaseolus vulgaris epidemics [3,22]. 


\section{Recombination as a driving force in monocot geminiviruses: MSV}

Maize streak virus (MSV), a well characterized leafhopper-transmitted geminivirus from the Mastrevirus genus of the family Geminiviridae, is the causal agent of maize streak disease. It ranks amongst the most serious biological threats to food security in sub-Saharan Africa [5]. Clear imprints of both ancient and recent recombination events can be detected on most MSV genomes. The ability of recombination to rapidly produce viruses with altered characteristics was confirmed in a study that us sub-optimal synthetic recombinant viruses and where fitter genome were quickly restored [27]. Another step further, it was also suggested that recombination was cardinal in the emergence of new biological features. In fact, whereas at least eleven distinct MSV strains have been reported so far from several common grasses in Africa, only the MSV-A causes severe disease in maize [4]. Interestingly, it was suggested that this MSV-A strain is in fact a recombinant between two Digitaria-adapted MSV strains that replicate to low level in maize and barely cause symptoms [4]. From a phylogeographic reconstruction, it was inferred that this recombinant emerged in the 1860 s in southern Africa before spreading throughout Africa in the 1950s where it is today found widespread $[51,60]$. While this recombination event might have produced a virus with increased severity in maize, the studies highlight the possibility that it may also have enabled MSV-A to spread more efficiently by allowing it to

Figure 1

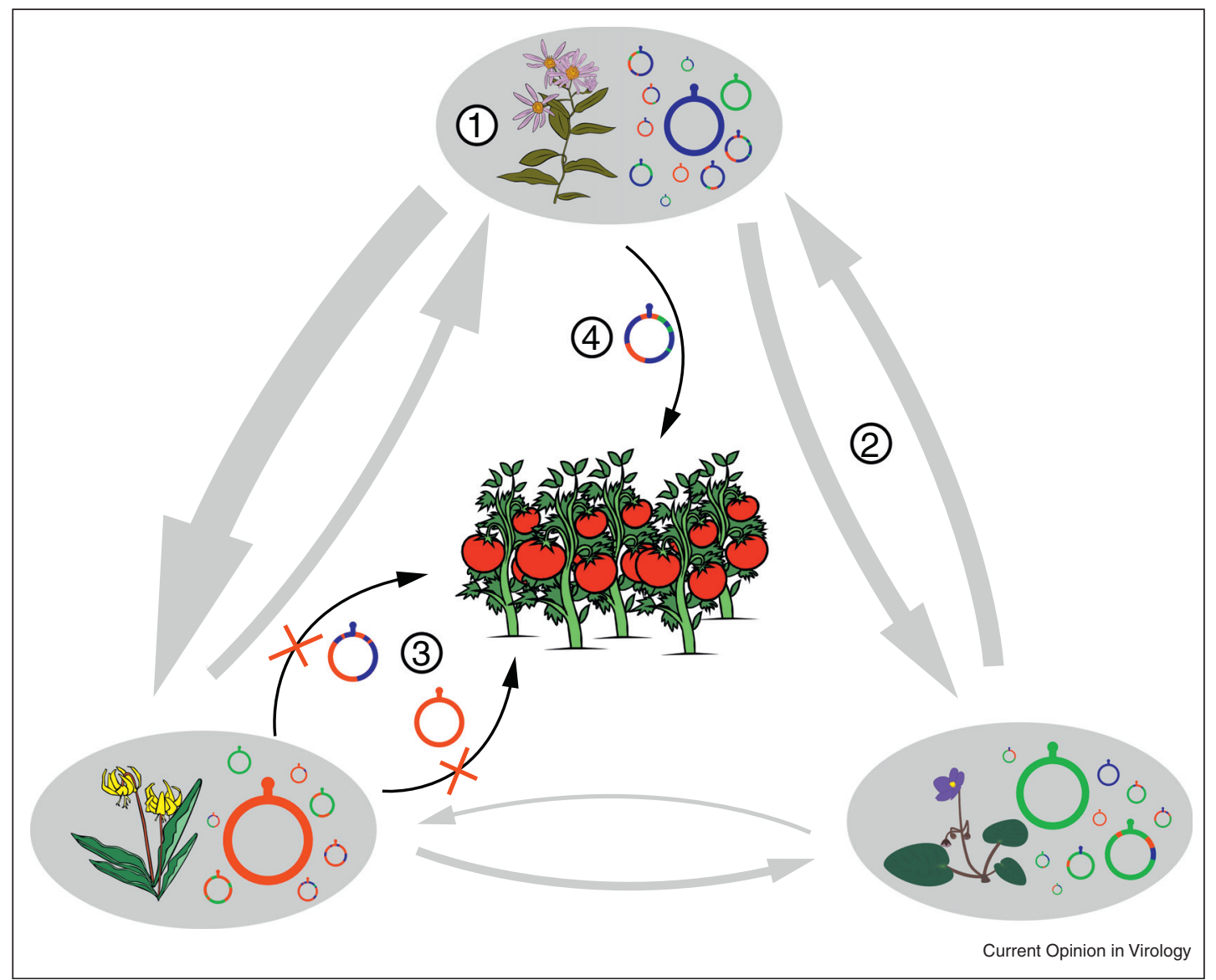

Schematic representation of geminivirus communities in a multi-host plant system, with a virus free host (here, tomato plants in the middle of the figure) and three uncultivated plant species. Each of the uncultivated plants is the host of a set of viruses (1) with contrasting degree of fitness. Rate of virus exchanges between the hosts (2) is determined by vector populations densities and preferences and by virus adaptation to each host. The topology of the network and the available sequence space determine in part the set of viruses (several of which being recombinant) that can appear. Whereas some viruses won't be able to infect the yet disease free plant (3), some others (4) with the appropriate combinations of genetic determinants will eventually be successful and potentially emerge as a proper circulating viruses on this new host. Although the figure represents the first steps of an emergence event on a crop, a process facilitated by its high density, it must be noticed that viral emergence function as a natural process within the ecosystems on potentially every plant species, cultivated or not. 
infect a wider variety of hosts. In fact, MSV-A was detected on members of eight different grass genera, thus having the largest host range of all MSV strains [4]. Although it remains unknown whether this recombination event was pivotal in the emergence of MSV-A in maize, its enlarged host range might explain the ecological success of this recombinant virus.

\section{Conclusions - future work}

The expansion of monocultures and/or spread of polyphageous vectors (such as specific types of B. tabaci for begomoviruses), that favour movement of indigenous viruses between plants, are major ecological drivers of recent geminivirus host switches. While the contribution of recombination is clearly apparent (Figure 1), one of the greatest challenges is understanding the interplay between recombination and viral ecology. Whereas the vast majority of geminivirus sequences obtained in the last years are from viruses infecting cultivated plants, they most likely emerge from non-cultivated plants (stands for plant pathogens in general [61]). In this context, it would be extremely informative to first isolate large sets of virus sequences at the ecosystem scale before exhaustively inferring their host ranges. Several ongoing projects using metagenomics approaches will certainly pave the way to such understanding $\left[62^{\circ}, 63,64\right]$. The analyses of the recombination patterns within these viral communities could inform about virus ecology. Since recombining viruses obviously have somewhat overlapping geographical distributions, host ranges and tissue tropisms, and patterns of sequence exchange amongst viruses sampled from nature could also be used to retrace the ecological interactions between populations (see $[65,66]$ for a good examples on bacteria). Whereas the networks of genetic exchanges amongst viruses could inform about virus populations that are the most active recombiners, their analyses could reveal key host species, environmental or cultural conditions favouring specific patterns of viral encounter and from where host switch is most likely to originate. The topology of the circuits of genetic exchanges within and between virus communities would determine the probability of viruses to form new genetic combinations and to emerge in a specific spot of the fitness landscape [67]. Knowing their great success as emerging pathogens and their presumed high prevalence in most ecosystems [63,64,68-70], geminiviruses stand as an excellent model to further study emergence at the global ecosystem scale where it functions as a natural process during virus evolution.

\section{Acknowledgements}

This work was funded by grants awarded to E.M. (Grant AGL2013-48913C2-1-R from the Ministerio de Ciencia e Innovación with assistance from the European Regional Development Fund, and Código P10-AGR-6516 from Junta de Andalucía). P.L. is funded by the Région Réunion, the European Union (FEDER) and the CIRAD.

\section{References and recommended reading}

Papers of particular interest, published within the period of review, have been highlighted as:

- of special interest

•• of outstanding interest

1. Martin DP, Biagini $P$, Lefeuvre $P$, Golden $M$, Roumagnac $P$, Varsani A: Recombination in eukaryotic single stranded DNA viruses. Viruses 2011, 3:1699-1738.

2. Padidam M, Sawyer S, Fauquet CM: Possible emergence of new geminiviruses by frequent recombination. Virology 1999 , 265:218-225.

3. García-Andrés S, Accotto GP, Navas-Castillo J, Moriones E: Founder effect, plant host, and recombination shape the emergent population of begomoviruses that cause the tomato yellow leaf curl disease in the Mediterranean basin. Virology 2007, 359:302-312.

4. Varsani A, Shepherd DN, Monjane AL, Owor BE, Erdmann JB, Rybicki EP, Peterschmitt M, Briddon RW, Markham PG, Oluwafemi S et al.: Recombination, decreased host specificity and increased mobility may have driven the emergence of maize streak virus as an agricultural pathogen. J Gen Virol 2008, 89:2063-2074.

5. Shepherd DN, Martin DP, Van der Walt E, Dent K, Varsani A, Rybicki EP: Maize streak virus: an old and complex 'emerging' pathogen. Mol Plant Pathol 2010, 11:1-12.

6. Navas-Castillo J, Fiallo-Olivé E, Sánchez-Campos S: Emerging virus diseases transmitted by whiteflies. Annu Rev Phytopathol 2011, 49:219-248.

7. Rey MEC, Ndunguru J, Berrie LC, Paximadis M, Berry S, Cossa N, Nuaila N, Mabasa KG, Abraham N, Rybicki EP et al.: Diversity of dicotyledenous-infecting geminiviruses and their associated DNA molecules in Southern Africa, including the South-West Indian Ocean islands. Viruses 2012, 4:1753-1791.

8. Varsani A, Navas-Castillo J, Moriones E, Hernández-Zepeda C, Idris A, Brown J, Zerbini FM, Martin DP: Establishment of three new genera in the family Geminiviridae: Becurtovirus, Eragrovirus and Turncurtovirus. Arch Virol 2014, 159:21932203.

9. Duffy S, Shackelton LA, Holmes EC: Rates of evolutionary change in viruses: patterns and determinants. Nat Rev Genet 2008, 9:267-276.

10. Lefeuvre P, Lett J-M, Varsani A, Martin DP: Widely conserved recombination patterns among single-stranded DNA viruses. J Virol 2009, 83:2697-2707.

11. Parrish CR, Holmes EC, Morens DM, Park E-C, Burke DS, Calisher CH, Laughlin CA, Saif LJ, Daszak P: Cross-species virus transmission and the emergence of new epidemic diseases. Microbiol Mol Biol Rev 2008, 72:457-470.

12. Krupovic M: Networks of evolutionary interactions underlying - the polyphyletic origin of ssDNA viruses. Curr Opin Virol 2013, 3:578-586.

This work highlights the diversity and versatility of ssDNA viruses in general and review some of the current hypothesis on their genesis.

13. Roux S, Enault F, Bronner G, Vaulot D, Forterre P, Krupovic M: Chimeric viruses blur the borders between the major groups of eukaryotic single-stranded DNA viruses. Nat Commun 2013, 4:2700.

14. Ding SW: RNA-based antiviral immunity. Nat Rev Immunol 2010, 10:632-644.

15. Díaz-Pendón JA, Ding SW: Direct and indirect roles of viral suppressors of RNA silencing in pathogenesis. Annu Rev Phytopathol 2008, 46:303-326.

16. Luna AP, Morilla G, Voinnet $O$, Bejarano ER: Functional analysis - of gene-silencing suppressors from Tomato yellow leaf curl disease viruses. Mol Plant Microbe Interact 2012, 25:1294-1306. First comprehensive study proving that virus-host interaction can be determined by gene-silencing mechanisms and that genetic exchange of silencing suppressors are potentially associated to host shift and emergence. 
17. Xie $Y$, Zhao L, Jiao X, Jiang $T$, Gong H, Wang B, Briddon RW, Zhou $X$ : A recombinant begomovirus resulting from exchange of the C4 gene. J Gen Virol 2013, 94:1896-1907.

18. Fargette D, Konaté G, Fauquet C, Muller E, Peterschmitt M, Thresh JM: Molecular ecology and emergence of tropical plant viruses. Annu Rev Phytopathol 2006, 44:235-260.

19. Jones RAC: Plant virus emergence and evolution: origins, new encounter scenarios, factors driving emergence, effects of changing world conditions, and prospects for control. Virus Res 2009, 141:113-130.

20. Legg JP, Fauquet CM: Cassava mosaic geminiviruses in Africa. Plant Mol Biol 2004, 56:585-599.

21. Lima ATM, Sobrinho RR, González-Aguilera J, Rocha CS, Silva SJC, Xavier CAD, Silva FN, Duffy S, Zerbini FM: Synonymous site variation due to recombination explains higher genetic variability in begomovirus populations infecting non-cultivated hosts. J Gen Virol 2013, 94:418-431.

22. Monci F, Sánchez-Campos S, Navas-Castillo J, Moriones E: A natural recombinant between the geminiviruses tomato yellow leaf curl sardinia virus and tomato yellow leaf curl virus exhibits a novel pathogenic phenotype and is becoming prevalent in Spanish populations. Virology 2002, 303:317-326.

23. García-Andrés S, Monci F, Navas-Castillo J, Moriones E: Begomovirus genetic diversity in the native plant reservoir solanum nigrum: evidence for the presence of a new virus species of recombinant nature. Virology 2006, 350:433-442.

24. Briddon RW, Akbar F, lqbal Z, Amrao L, Amin I, Saeed M,

- Mansoor S: Effects of genetic changes to the begomovirus/ betasatellite complex causing cotton leaf curl disease in South Asia post-resistance breaking. Virus Res 2014, 186:114119.

This study demonstrates from field data the rapid evolution of geminivirus populations through recombination to adapt to environmental changes such as the selective pressure associated to the generalized use of virusresistant plant genotypes.

25. Lefeuvre P, Lett J-M, Reynaud B, Martin DP: Avoidance of protein fold disruption in natural virus recombinants. PLOS Pathog 2007, 3:e181.

26. Martin DP, van der Walt E, Posada D, Rybicki EP: The evolutionary value of recombination is constrained by genome modularity. PLoS Genet 2005, 1:e51.

27. Monjane AL, Martin DP, Lakay F, Muhire BM, Pande D, Varsani A,

- Harkins G, Shepherd DN, Rybicki EP: Extensive recombinationinduced disruption of genetic interactions is highly deleterious but can be partially reversed by small numbers of secondaryrecombination events. J Virol 2014, 88:7843-7851.

Synthetic maize streak virus genome chimeras with severe fitness costs owe to disruptions of genetic interactions were used to demonstrate with elegant experiments that fully adapted viruses can be rapidly restored via secondary recombination to adaptively reverse almost lethal recombination events.

28. Preiss $\mathrm{W}$, Jeske $\mathrm{H}$ : Multitasking in replication is common among geminiviruses. J Virol 2003, 77:2972-2980.

29. Jeske $H$, Lütgemeier $M$, Preiss $W$ : DNA forms indicate rolling circle and recombination-dependent replication of Abutilon mosaic virus. EMBO J 2001, 20:6158-6167.

30. Martin DP, Lefeuvre P, Varsani A, Hoareau M, Semegni JY, Dijoux B, Vincent C, Reynaud B, Lett JM: Complex recombination patterns arising during geminivirus coinfections preserve and demarcate biologically important intra-genome interaction networks. PLoS Pathog 2011, 7:e1002203.

31. Voigt CA, Martínez C, Wang ZG, Mayo SL, Arnold FH: Protein building blocks preserved by recombination. Nat Struct Bio 2002, 9:553-558

32. Pita JS, Fondong VN, Sangaré A, Otim-Nape GW, Ogwal S, Fauquet CM: Recombination, pseudorecombination and synergism of geminiviruses are determinant keys to the epidemic of severe cassava mosaic disease in Uganda. J Gen Virol 2001, 82:655-665.
33. Briddon RW, Patil BL, Bagewadi B, Nawaz-ul-Rehman MS, Fauquet CM: Distinct evolutionary histories of the DNA-A and DNA-B components of bipartite begomoviruses. BMC Evol Biol 2010, 10:97.

34. Silva F, Lima A, Rocha C, Castillo-Urquiza G, Alves-Junior M, Zerbini F: Recombination and pseudorecombination driving the evolution of the begomoviruses Tomato severe rugose virus (ToSRV) and Tomato rugose mosaic virus (ToRMV): two recombinant DNA-A components sharing the same DNA-B. Virol J 2014, 11:66.

35. Zhou X: Advances in understanding begomovirus satellites. Annu Rev Phytopathol 2013, 51:357-381.

36. Ranjan P, Singh AK, Kumar RV, Basu S, Chakraborty S: Hostspecific adaptation of diverse betasatellites associated with distinct Indian tomato-infecting begomoviruses. Virus Genes 2014, 48:334-342.

37. Chen L-F, Rojas M, Kon T, Gamby K, Xoconostle-Cazares B, Gilbertson RL: A severe symptom phenotype in tomato in Mali is caused by a reassortant between a novel recombinant begomovirus (Tomato yellow leaf curl Mali virus) and a betasatellite. Mol Plant Pathol 2009, 10:415-430.

38. Hou YM, Gilbertson RL: Increased pathogenicity in a pseudorecombinant bipartite geminivirus correlates with intermolecular recombination. J Virol 1996, 70:5430-5436.

39. Stenger DC, Davis KR, Bisaro DM: Recombinant beet curly top virus genomes exhibit both parental and novel pathogenic phenotypes. Virology 1994, 200:677-685.

40. Schnippenkoetter WH, Martin DP, Hughes FL, Fyvie M, Willment JA, James D, von Wechmar MB, Rybicki EP: The relative infectivities and genomic characterisation of three distinct mastreviruses from South Africa. Arch Virol 2001, 146:10751088.

41. Briddon RW, Pinner MS, Stanley J, Markham PG: Geminivirus coat protein gene replacement alters insect specificity. Virology 1990, 177:85-94.

42. Qin Y, Petty ITD: Genetic analysis of bipartite geminivirus tissue tropism. Virology 2001, 291:311-323.

43. Martin DP, Rybicki EP: Investigation of maize streak virus pathogenicity determinants using chimaeric genomes. Virology 2002, 300:180-188.

44. Morra MR, Petty ITD: Tissue specificity of geminivirus infection is genetically determined. Plant Cell 2000, 12:2259-2270.

45. Zhou X, Liu Y, Calvert L, Munoz C, Otim-Nape GW, Robinson DJ, Harrison BD: Evidence that DNA-A of a geminivirus associated with severe cassava mosaic disease in Uganda has arisen by interspecific recombination. J Gen Virol 1997, 78:2101-2111.

46. Sanz Al, Fraile A, García-Arenal F, Zhou X, Robinson DJ, Khalid S, Butt T, Harrison BD: Multiple infection, recombination and genome relationships among begomovirus isolates found in cotton and other plants in Pakistan. J Gen Virol 2000, 81:18391849.

47. Ribeiro SG, Ambrozevícius LP, Avila AC, Bezerra IC, Calegario RF, Fernandes JJ, Lima MF, de Mello RN, Rocha H, Zerbini FM: Distribution and genetic diversity of tomato-infecting begomoviruses in Brazil. Arch Virol 2003, 148:281-295.

48. Zhou X, Liu Y, Robinson DJ, Harrison BD: Four DNA-A variants among Pakistani isolates of cotton leaf curl virus and their affinities to DNA-A of geminivirus isolates from okra. J Gen Virol 1998, 79:915-923.

49. Rocha CS, Castillo-Urquiza GP, Lima ATM, Silva FN, Xavier CAD

- Hora-Júnior BT, Beserra-Junior JEA, Malta AWO, Martin DP Varsani $A$ et al.: Brazilian begomovirus populations are highly recombinant, rapidly evolving, and segregated based on geographical location. J Virol 2013, 87:5784-5799.

This extensive study of geminiviruses present in cultivated and wild hosts demonstrates the ability of recombination to generate variable virus populations that are the substrate for rapid host adaptation within genetically diverse hosts communities. 
50. Lefeuvre P, Martin DP, Harkins G, Lemey P, Gray AJA, Meredith S, Lakay F, Monjane A, Lett JM, Varsani A et al.: The spread of tomato yellow leaf curl virus from the Middle East to the world. PLoS Pathog 2010, 6:e1001164.

51. Monjane AL, Harkins GW, Martin DP, Lemey P, Lefeuvre P, Shepherd DN, Oluwafemi S, Simuyandi M, Zinga I, Komba EK et al.: Reconstructing the history of maize streak virus strain a dispersal to reveal diversification hot spots and its origin in southern Africa. J Virol 2011, 85:9623-9636.

52. Brown JK, Fauquet CM, Briddon RW, Zerbini M, Moriones E, Navas-Castillo J: Geminiviridae. In Virus Taxonomy, Ninth Report of the ICTV. Edited by King AMQ, Adams MJ, Carstens EB, Lefkowitz EJ. Elsevier/Academic Press; 2012:351-373.

53. Péréfarres $F$, Thierry $M$, Becker $N$, Lefeuvre $P$, Reynaud $B$, Delatte H, Lett JM: Biological invasions of geminiviruses: case study of TYLCV and Bemisia tabaci in Reunion Island. Viruses 2012, 4:3665-3688.

54. Patil BL, Fauquet CM: Cassava mosaic geminiviruses: actual knowledge and perspectives. Mol Plant Pathol 2009, 10:685707.

55. Abhary M, Patil BL, Fauquet CM: Molecular biodiversity, taxonomy, and nomenclature of tomato yellow leaf curl-like viruses. In Tomato Yellow Leaf Curl Virus Disease. Edited by Czosnek H. Netherlands: Springer; 2007:85-118.

56. Davino S, Miozzi L, Panno S, Rubio L, Davino M, Accotto GP. Recombination profiles between Tomato yellow leaf curl virus and Tomato yellow leaf curl Sardinia virus in laboratory and field conditions: evolutionary and taxonomic implications. $J$ Gen Virol 2012, 93:2712-2720.

57. Urbino C, Gutiérrez S, Antolik A, Bouazza N, Doumayrou J,

- Granier M, Martin DP, Peterschmitt M: Within-host dynamics of the emergence of tomato yellow leaf curl virus recombinants. PLOS ONE 2013, 8:e58375.

This study, confirming previous work on geminiviruses, demonstrated that within co-infected plants, a floury of recombinant viruses can rapidly be generated and maintained. The respective roles of random and deterministic factors are highlighted.

58. Vuillaume F, Thebaud G, Urbino C, Forfert N, Granier M, Froissart R, Blanc S, Peterschmitt M: Distribution of the phenotypic effects of random homologous recombination between two virus species. PLoS Pathog 2011, 7:e1002028.

59. Davino S, Napoli C, Dellacroce C, Miozzi L, Noris E, Davino M, Accotto GP: Two new natural begomovirus recombinants associated with the tomato yellow leaf curl disease co-exist with parental viruses in tomato epidemics in Italy. Virus Res 2009, 143:15-23.
60. Owor BE, Martin DP, Shepherd DN, Edema R, Monjane AL, Rybicki EP, Thomson JA, Varsani A: Genetic analysis of maize streak virus isolates from Uganda reveals widespread distribution of a recombinant variant. J Gen Virol 2007, 88:31543160.

61. Roossinck MJ: Plant virus metagenomics: biodiversity and ecology. Annu Rev Genet 2012, 46:359-369.

62. Vayssier-Taussat M, Albina E, Citti C, Cosson J-F, Jacques M-A,

- Lebrun M-H, Le Loir Y, Ogliastro M, Petit MA, Roumagnac P et al. Shifting the paradigm from pathogens to pathobiome: new concepts in the light of meta-omics. Front Cell Infect Microbiol 2014, 5:4.

In this review the authors shed light on the necessity to study the pathogens at the ecosystem level to notably get of full understanding of disease emergence. The contribution of metagenomic approaches to explore microbial communities is discussed.

63. Yoshida M, Takaki Y, Eitoku M, Nunoura T, Takai K: Metagenomic analysis of viral communities in (HADO) pelagic sediments. PLOS ONE 2013, 8:e57271.

64. Ng TFF, Duffy S, Polston JE, Bixby E, Vallad GE, Breitbart M: Exploring the diversity of plant DNA viruses and their satellites using vector-enabled metagenomics on whiteflies. PLOS ONE 2011, 6:e19050.

65. Luo C, Walk ST, Gordon DM, Feldgarden M, Tiedje JM, Konstantinidis KT: Genome sequencing of environmental Escherichia coli expands understanding of the ecology and speciation of the model bacterial species. Proc Natl Acad Sci USA 2011, 108:7200-7205.

66. Popa O, Hazkani-Covo E, Landan G, Martin W, Dagan T: Directed networks reveal genomic barriers and DNA repair bypasses to lateral gene transfer among prokaryotes. Genome Res 2011, 21:599-609.

67. Manrubia SC: Modelling viral evolution and adaptation: challenges and rewards. Curr Opin Virol 2012, 2:531-537.

68. Smith RJ, Jeffries TC, Roudnew B, Seymour JR, Fitch AJ, Simons KL, Speck PG, Newton K, Brown MH, Mitchell JG: Confined aquifers as viral reservoirs. Environ Microbiol Rep 2013, 5:725-730.

69. Rosario K, Padilla-Rodriguez M, Kraberger S, Stainton D, Martin DP, Breitbart M, Varsani A: Discovery of a novel mastrevirus and alphasatellite-like circular DNA in dragonflies (Epiprocta) from Puerto Rico. Virus Res 2013, 171:231-237.

70. Whon TW, Kim M-S, Roh SW, Shin N-R, Lee H-W, Bae J-W: Metagenomic characterization of airborne viral DNA diversity in the near-surface atmosphere. J Virol 2012, 86:8221-8230. 